\title{
Predicting Chemistry Achievement through Task Value, Goal Orientations, and Self- Efficacy: A Structural Model
}

\author{
Esen Uzuntiryaki-Kondakci and Ayse Senay \\ Middle East Technical University
}

\section{Abstract}

The purpose of the study was to examine the relationships between task value, goal orientations, and chemistry self-efficacy in predicting $11^{\text {th }}$ grade Turkish students' chemistry achievement. A total of 572 eleventh grade students taking chemistry participated in the study. Data were collected using the Motivated Strategies for Learning Questionnaire, Achievement Goal Questionnaire, Chemistry Self-Efficacy Scale, and Chemistry Achievement Test. Results of structural equation modeling indicated that task value was a significant positive predictor of mastery-approach goals, performance-approach goals, and mastery-avoidance goals. Mastery-approach goals and performance-approach goals were found to be positive predictors of chemistry self-efficacy for cognitive skills, whereas masteryavoidance goals negatively predicted chemistry self-efficacy for cognitive skills. Lastly, chemistry self-efficacy for cognitive skills was a significant positive predictor of chemistry achievement. Overall, the findings of the present study extend the existing body of literature on the interplay between task value, goal orientations, and chemistry self-efficacy in predicting chemistry achievement.

Key words: chemistry achievement; goal orientation; self-efficacy; structural equation modeling; task value.

\section{Introduction}

For more than two decades there has been an increase of the body of literature examining the interrelationships among motivational variables to predict achievement. In particular, most of the studies reported the significant role of task value, goal 
orientations, and self-efficacy on achievement (e.g., Elliot \& McGregor, 1999; Hampton \& Mason, 2003; Kaplan \& Maehr, 1999; Pajares \& Miller, 1994; Phan, 2009; Pintrich \& Schunk, 2007; Wigfield, 1994). Investigating the interplay among these variables in an integrated framework is important for understanding the nature of motivational factors, identifying the determinant and mediating role of such variables in predicting performance, and in turn, developing strategies to enhance student achievement. Accordingly, the purpose of the present study was to examine the relationships among task value, goal orientations, and self-efficacy in predicting $11^{\text {th }}$ grade Turkish students' chemistry achievement. In the following text, the theoretical framework of the motivational constructs used in this study are explained.

Task value has been examined under the expectancy-value theory. This theory suggests that achievement behavior is a function of motives, expectancies for success, and values. In other words, individuals' dispositions for achievement, their subjective beliefs about the probability of having success in a future task, and the value that they attach to the task affect their performance (Atkinson 1957, as cited in Wigfield \& Eccles, 1992). In the current model of the expectancy-value theory, Eccles et al. (1983), consider task value in terms of four elements: (a) attainment value; importance of the task to the individual, (b) intrinsic value; individual's enjoyment in doing the task, (c) utility value; usefulness of the task to satisfy further goals, and (d) cost; consequences of engaging in a task. Eccles and Wigfield (1995) claim that if a particular task for a person has the potential in satisfying the needs and promoting the attainment of goals, and if it confirms the personal values, the person tends to give value to and engage in that task. In the model, task value is related to actual achievement. Recent research has also highlighted the importance of task value in predicting achievement (Bong, 2001; Pintrich \& Schunk, 2007; Yumusak et al., 2007). However, there is still a question about whether an individual values a task that $\mathrm{s} / \mathrm{he}$ is competent at or whether $\mathrm{s} / \mathrm{he}$ develops value of that task as a result of competence (Pintrich \& Schunk, 2007). The present study, therefore, intends to shed light on the role of task value on achievement by taking goal orientations and self-efficacy into account.

Goal orientation reflects "different ways of approaching, engaging in, and responding to achievement type activities" (Ames, 1992, p. 261) and therefore affects achievement. It has been defined as reasons for why and how individuals strive to achieve their objectives (Ames, 1992; Anderman \& Maehr, 1994). Early studies on goal orientation proposed a dichotomous model with two main types of goals as mastery and performance (Ames, 1992; Dweck, 1986), and a trichotomous model involving mastery goals, performance-approach goals, and performance-avoidance goals (Elliot, 1997; Elliot \& Harackiewicz, 1996). Recently, researchers have extended this model by conceptualizing a fourth achievement goal, namely mastery-avoidance goals, in a $2 \mathrm{x}$ 2 Achievement Goal Framework (Elliot \& McGregor, 2001). In the present study, this $2 \times 2$ framework was used to identify students' goal orientations.

Students with mastery-approach goals aim at learning for personal development. Mastery-avoidance goals, on the other hand, are related to avoiding failure in reaching 
a particular standard of task accomplishment. Performance-approach goal orientation is related to students' desire to outperform others, whereas performance-avoidance goal orientation refers to the desire to avoid failure compared to other students (Elliot, 1997; Elliot \& Harackiewicz, 1996). In general, research studies indicated that there is a relationship between approach-oriented goals and positive outcomes like persistence, high levels of self-efficacy, and high grades (Elliot \& McGregor, 1999; Kaplan \& Maehr, 1999; Phan, 2009; Tanaka \& Yamauchi, 2001; Utman, 1997). In contrast, avoidance-oriented goals were associated with low levels of self-efficacy, high anxiety, and low exam performance (Elliot, 1999; Elliot \& McGregor, 1999; Urdan et al., 2002). Elliot (1999) stressed that students' choice of particular types of goals depends on psychological and environmental factors.

Self-efficacy, a central construct of the social cognitive theory, has been defined as "people's judgments of their capabilities to organize and execute courses of action required to attain designated types of performances" (Bandura, 1986, p. 391). Bandura characterized self-efficacy beliefs as being task and domain specific. Students might have different self-efficacy judgments in different types of domains or tasks. For example, a student who feels efficient in chemistry might not feel efficient in mathematics. Thus, students' self-efficacy beliefs should be investigated for each specific domain. In the present study, we dealt with self-efficacy in the context of chemistry. In line with Bandura's definition, chemistry self-efficacy can be described as students' beliefs in their abilities to perform chemistry tasks successfully (Uzuntiryaki \& Capa Aydin, 2009). Social cognitive theory proposes that individuals' beliefs influence their thoughts, behaviors, and performance. Therefore, it is expected that self-efficacy plays an essential role in choosing science-related activities, exerting effort, showing persistence, and completing tasks successfully. Indeed, many research studies showed that self-efficacy was the most reliable predictor of students' achievement (Britner, 2008; Britner \& Pajares, 2006; Cavallo et al., 2004; Lau \& Roeser, 2002; Pintrich \& De Groot, 1990).

\section{The Present Study}

The purpose of the present study was to examine the relationships among task value, goal orientations, and self-efficacy in predicting $11^{\text {th }}$ grade students' chemistry achievement. We took task value as a starting point in this investigation, considering its role in the achievement indicated by both the theory (Eccles et al., 1983) and empirical studies (Pintrich \& Schunk, 2007; Yumusak et al., 2007). In addition, Miller and Brickman (2004) proposed that when individuals perceive a task valuable for studying, they tend to set mastery goals. Other researchers also emphasized the predictive role of task value on adoption of goals (Greene et al., 2004; Liem et al., 2008; Sungur, 2007). Considering these relations, we set task value as a predictor of goal orientations in the model we proposed.

Research studies yielded inconsistent results about the relationship between goal orientations and self-efficacy. While some studies (Fenollar et al., 2007; Greene et al., 2004; Liem et al., 2008) indicated that self-efficacy was the predictor of achievement 
goals, other studies, however, pointed out that achievement goals significantly predicted self-efficacy (Middleton \& Midgley, 1997; Pajares et al., 2000; Phan, 2009; Yi \& Hwang, 2003). Dweck and Leggett (1988) stated that students with mastery learning orientation had positive affect and intrinsic motivation when faced with challenges. These students tend to enjoy learning new challenging ideas and develop self-efficacy. Moreover, Pintrich and Schunk (2007) suggested that students with mastery goals are likely to evaluate feedbacks to monitor their progress and thereby, develop efficacy beliefs. For high school students, performance goals have been found to be related to self-efficacy (Skaalvik, 1997; Wolters et al., 1996). Therefore, we set achievement goals as a predictor of chemistry self-efficacy in the current study. Finally, chemistry selfefficacy was set as a predictor of chemistry achievement considering both the theory (Bandura, 1986) and the results of the empirical studies (e.g., Britner \& Pajares, 2006; Lau \& Roeser, 2002). Consequently, the hypotheses of the study were as follows:

Hypothesis 1 . Task value will be a positive predictor of goal orientations (i.e., mastery-approach goals, mastery-avoidance goals, performance-approach goals, and performance-avoidance goals).

Hypothesis 2. Goal orientations will be a positive predictor of chemistry self-efficacy (i.e., chemistry self-efficacy for cognitive skills and self-efficacy for chemistry laboratory).

Hypothesis 3 . Chemistry self-efficacy will be a positive predictor of chemistry achievement.

Hypothesis 4 . The relationship between goal orientations and chemistry achievement will be mediated by chemistry self-efficacy.

Hypothesis 5 . The relationship between task value and chemistry achievement will be mediated by goal orientations and chemistry self-efficacy.

Figure 1 depicts the proposed model of the study.

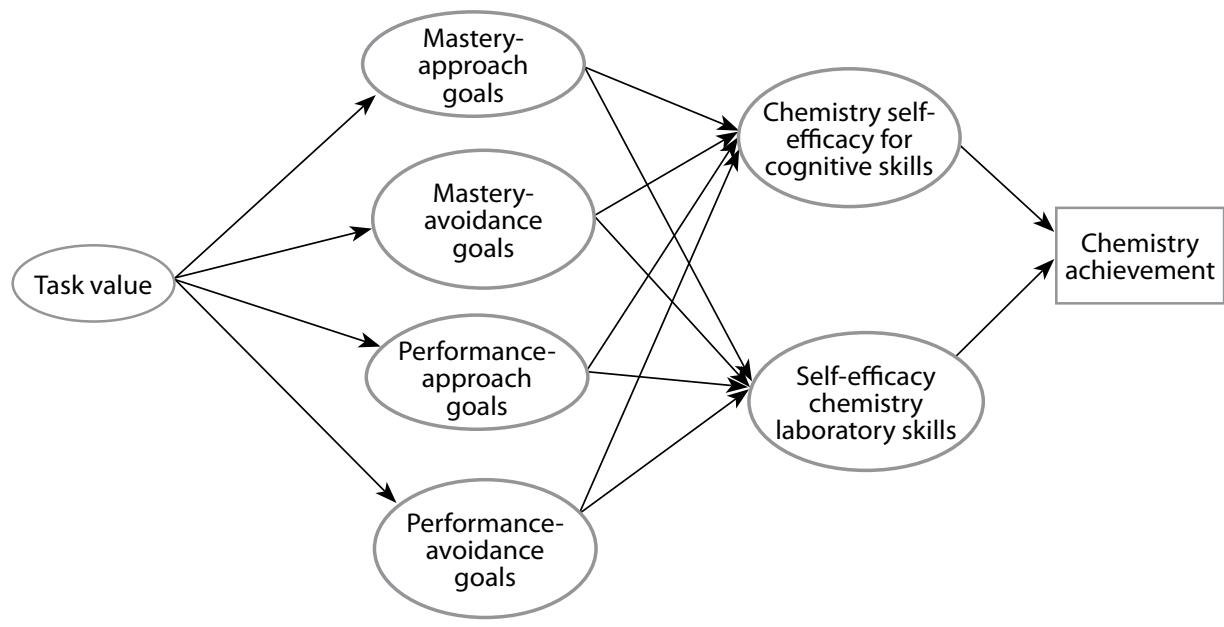

Figure 1. The conceptual model of the relationship between task value, goal orientations, chemistry self-efficacy, and chemistry achievement 


\section{Methods \\ Participants}

The participants in the study were 572 eleventh grade students (323 females and 249 males), who have been taking chemistry class, from seven different public high schools in Ankara, Turkey. The mean age of students was 17.03 ( $S D=.33$ ). Participation was voluntary. The students were informed about the study and given instructions on answering the items of the instruments, requested to co-operate with the researcher by being honest in answering the items of the scales and tests, and were informed that their answers would be held confidential and not influence their school grades in any way. It took approximately 50 minutes to complete the instruments.

\section{Instruments}

Four instruments were used to collect data:

Task Value. Task value sub-dimension of the Motivated Strategies for Learning Questionnaire (MSLQ; Pintrich et al., 1991) was used to identify students' perceptions about the importance of chemistry. The scale was adapted into Turkish by Sungur (2004). The MSLQ has been broadly used in literature either fully or selected subscales were used for the purpose of the study. In the present study, task value sub-dimension was used for the context of chemistry. It includes 6 items with 7-point rating scale ranging from 1 (not at all true of me) to 7 (very true of me). A sample item was "It is important for me to learn the course material in this class." The Cronbach's alpha reliability estimate was found to be .89 .

The Achievement Goal Questionnaire. It was developed by Elliot and McGregor (2001) to assess reasons why and how students participate in a learning activity. It consists of four dimensions: Mastery-approach goals, mastery-avoidance goals, performance-approach goals, and performance-avoidance goals. The instrument is a self-report questionnaire which included 15 items on a 5-point scale from 1 (never) to 5 (always). The instrument was adapted into Turkish by Senler and Sungur (2007). Sample items include: "I desire to completely master the material presented in this class," "I worry that I may not learn all that I possibly could in this class," "It is important for me to do better than other students," and "I just want to avoid doing poorly in this class compared to others." The Cronbach's alpha reliability estimate was found to be .79 for mastery-approach goals, .76 for mastery-avoidance goals, .77 for performance-approach goals, and .78 for performance-avoidance goals.

Chemistry Self-Efficacy Scale (CSES). It was developed by Capa Aydin and Uzuntiryaki (2009) to assess high school students' beliefs in their ability to successfully perform chemistry tasks. The scale is comprised of 16 items on two dimensions as chemistry self-efficacy for cognitive skills (CSCS) and self-efficacy for chemistry laboratory (SCL). Students were supposed to rate their beliefs on a nine-point rating scale ranging from 1 (very poorly) to 9 (very well). Sample items were "How well can 
you describe the structure of an atom?" and "How well can you use the equipment in the chemistry laboratory?" The Cronbach's alpha reliability estimate was found to be .83 for CSCS and .95 for SCL.

Chemistry Achievement Test (CAT). This test was developed by researchers in order to assess students' chemistry knowledge on chemistry topics in the $11^{\text {th }}$ grade considering the chemistry curriculum of the Ministry of National Education for $11^{\text {th }}$ graders and chemistry textbooks. The test included 33 multiple-choice items on the following topics: Rate of chemical reactions, chemical equilibrium, solubility equilibrium, acids and bases, and electrochemistry. Besides having questions in the knowledge level, the test also included items which required higher order skills, like application and synthesis. Each item in the test was reviewed by four experts in chemistry education and the suggested changes were carried out regarding the content validity of the test. Before administering the test, a pilot study was conducted to analyze the test items and check the reliability coefficient. As a result of necessary changes, the test reliability coefficient was found to be .88 .

\section{Data Analysis}

Structural equation modeling (SEM) via Analysis of Moment Structures (AMOS) 7.0 (Arbuckle \& Wothke, 2006) was utilized to test the proposed model of the study. SEM is a statistical methodology for examining the relationships between a set of independent and dependent variables (Ullman, 2007). The independent variables in this study were task value, goal orientations, and chemistry self-efficacy. Students' chemistry achievement was the dependent variable. Before conducting SEM analysis for the proposed conceptual model, confirmatory factor analysis (CFA) was run to test the factor structure of the measurement model. The Non-Normed Fit Index (NNFI), Comparative Fit Index (CFI), and Root Mean Square Error of Approximation (RMSEA) with $90 \%$ confidence intervals were used along with the chi-square $\left(c^{2}\right)$ statistic since the $c^{2}$ statistic alone is deemed as unreliable (Byrne, 2001). Values greater than .90 indicate an adequate model fit (Kline, 1998), however, values higher than .95 are preferable (Hu \& Bentler, 1999). Browne and Cudeck (1993) suggest that RMSEA value less than .05 indicates close fit to model; value between .05 and .08 indicates mediocre fit, and value higher than .10 indicates poor fit. After ensuring that the measurement model had adequate fit, conceptual model was investigated. In addition, chi-square difference test was used (Yuan \& Bentler, 2004) to compare between full and partial mediation. Results of those analyses are provided in the results part.

Results

\section{Descriptive Statistics}

Mean, standard deviations, and correlations among variables of the study are presented in Table 1. It appeared that chemistry achievement was related to task value, mastery-approach goals, performance-approach goals, and CSCS, while not related to SCL, mastery-avoidance goals, and performance-avoidance goals. 
Table 1

Descriptive statistics for each variable and correlations among these variables

\begin{tabular}{lccccccccc}
\hline Variables & $M$ & $S D$ & 1 & 2 & 3 & 4 & 5 & 6 & 7 \\
\hline 1. Task value & 4.90 & 1.45 & & & & & & & \\
2. Mastery-approach goals & 4.09 & .77 & $.63^{* *}$ & & & & & & \\
3. Mastery-avoidance goals & 2.93 & .97 & $.25^{* *}$ & $.25^{* *}$ & & & & & \\
4. Performance-approach goals & 3.57 & .98 & $.33^{* *}$ & $.34^{* *}$ & $.26^{* *}$ & & & & \\
5. Performance-avoidance goals & 2.82 & .85 & .033 & .048 & $.34^{* *}$ & $.50^{* *}$ & & & \\
6. CSCS & 5.42 & 1.30 & $.48^{* *}$ & $.38^{* * *}$ & -.018 & $.23^{* *}$ & -.036 & & \\
7. SCL & 3.55 & 2.29 & $.14^{* *}$ & .016 & -.002 & .079 & .067 & $.31^{* *}$ & \\
8. Chemistry achievement & 16.05 & 4.93 & $.29^{* *}$ & $.23^{* *}$ & -.041 & $.14^{* *}$ & -.067 & $.24^{* *}$ & .031 \\
\hline
\end{tabular}

$\mathrm{N}=572$. Correlations are Pearson's $r$ coefficients. ${ }^{* *} \mathrm{p}<0.01$

\section{Confirmatory Factor Analysis}

The measurement model was tested via CFA. There were seven latent variables: task value, four goal orientations, and two chemistry self-efficacy variables. Each observed variable was loaded on each latent variable it was supposed to represent. The latent variables were allowed to correlate with each other. The factor loadings of observed variables to the assigned latent variables on the seven-factor measurement model are presented in Table 2. Results of $C F A$ yielded the following fit indices: $c^{2}(608)=1574.746$, $p<.05 ; \mathrm{NNFI}=.90 ; C F I=.91 ; R M S E A=.053(90 \% \mathrm{CI}=.050, .056)$. These values provided an adequate evidence for the factorial validity of the measurement model (Kline, 1998).

Table 2

Standardized factor loadings of the observed variables in the seven-factor measurement model

\begin{tabular}{lcc}
\hline Latent variables & $\begin{array}{c}\text { Observed } \\
\text { variables }\end{array}$ & $\begin{array}{c}\text { Factor } \\
\text { loadings }\end{array}$ \\
\hline Task value & 1 & .60 \\
& 3 & .81 \\
& 4 & .77 \\
& 5 & .78 \\
Mastery-approach goals & 6 & .77 \\
& 1 & .82 \\
Mastery-avoidance goals & 2 & .68 \\
& 3 & .76 \\
& 1 & .81 \\
Performance-approach goals & 2 & .66 \\
& 3 & .77 \\
& 1 & .73 \\
& 2 & .72 \\
& 3 & .69
\end{tabular}


Uzuntiryaki-Kondakci and Senay: Predicting Chemistry Achievement through Task Value, Goal ...

\begin{tabular}{|c|c|c|}
\hline Latent variables & $\begin{array}{l}\text { Observed } \\
\text { variables }\end{array}$ & $\begin{array}{l}\text { Factor } \\
\text { loadings }\end{array}$ \\
\hline \multicolumn{3}{|l|}{ Performance-avoidance } \\
\hline \multirow[t]{6}{*}{ goals } & 1 & .57 \\
\hline & 2 & .53 \\
\hline & 3 & .66 \\
\hline & 4 & .63 \\
\hline & 5 & .72 \\
\hline & 6 & .53 \\
\hline \multirow[t]{10}{*}{$\operatorname{CSCS}$} & 1 & .64 \\
\hline & 2 & .66 \\
\hline & 3 & .59 \\
\hline & 4 & .61 \\
\hline & 5 & .60 \\
\hline & 6 & .56 \\
\hline & 7 & .73 \\
\hline & 8 & .66 \\
\hline & 9 & .74 \\
\hline & 10 & .68 \\
\hline \multirow[t]{6}{*}{$\mathrm{SCL}$} & 1 & .88 \\
\hline & 2 & .88 \\
\hline & 3 & .81 \\
\hline & 4 & .90 \\
\hline & 5 & .89 \\
\hline & 6 & .86 \\
\hline
\end{tabular}

\section{Structural Equation Modeling}

Structural equation modeling (SEM) was used to test the hypotheses of the study. Latent variables were task value, four types of achievement goals (mastery-approach goals, mastery-avoidance goals, performance-approach goals, and performanceavoidance goals), and two dimensions of chemistry self-efficacy (CSCS and SCL). Two mediational models were tested:

(1) A baseline model (full mediation) consisted of a direct path from task value to goal orientations, from goal orientations to chemistry self-efficacy, and from chemistry self-efficacy to chemistry achievement as displayed in Figure 1. Results yielded a poor fit to the data $\left(c^{2}(652)=2008.145, p<.05 ; N N F I=.87 ; C F I=.88 ; R M S E A=.060 ; 90 \%\right.$ $C I=.057, .063)$. In an effort to improve the model fit, the modification indices (MI) were inspected (Byrne, 2001). MI suggested setting several error covariances free, leading to a reduction in the value of $c^{2}$ and thus, improvement of the model. Only theoretically meaningful modifications should be employed because of the theoretical nature of SEM. Therefore, we connected the error terms between item 6 (How well can you describe the structure of an atom?) and item 11 (How well can you explain the particulate nature of matter?) $(M I=70.52)$ in CSCS and between item 3 (How well can you carry out experimental procedures in the chemistry laboratory?) and item 4 (How well can you use the equipment in the chemistry laboratory?) ( $\mathrm{MI}=80.36)$ in SCL. In addition, the structural path between item 3 (I am very interested in the content area of the chemistry course) and item 5 (I like the subject matter of the chemistry 
course) in task value was freed $(\mathrm{MI}=68.26)$. These associations were expected since those items were in the same dimension and reflected similar content. The second CFA produced better-fit indices: $c^{2}(649)=1761.646, p<.05 ; N N F I=.90 ; C F I=.90$; RMSEA $=.055(90 \% \mathrm{CI}=.052, .058)$.

(2) The less-restrictive model (partial mediation) was obtained by adding direct paths from goal orientations to chemistry achievement in the baseline model. In addition, a direct path was added from task value to chemistry achievement. The results yielded the following fit indices: $c^{2}(644)=1738.109, p<.05 ; N N F I=.90 ; C F I=.90$; RMSEA $=.055(90 \% \mathrm{CI}=.051, .058)$. In order to test whether there is full or partial mediation, chi-square difference test was utilized between the baseline model (full mediation) and this less-restricted model (partial mediation). The results indicated that the less-restricted model (partial mediation) fits better $\left(c^{2}(5, N=572)=23.16\right.$; $p<.05$ ), which means that the relationship between goal orientations and chemistry achievement was partially mediated by chemistry self-efficacy. This test also revealed that the relationship between task value and chemistry achievement was partially mediated by goal orientations and chemistry self-efficacy. Since chi-square difference test yielded significant result and fit indices were satisfactory, the results of the lessrestricted model (partial mediation) were interpreted. Figure 2 displays the lessrestricted model (partial mediation) with the standardized path coefficients.

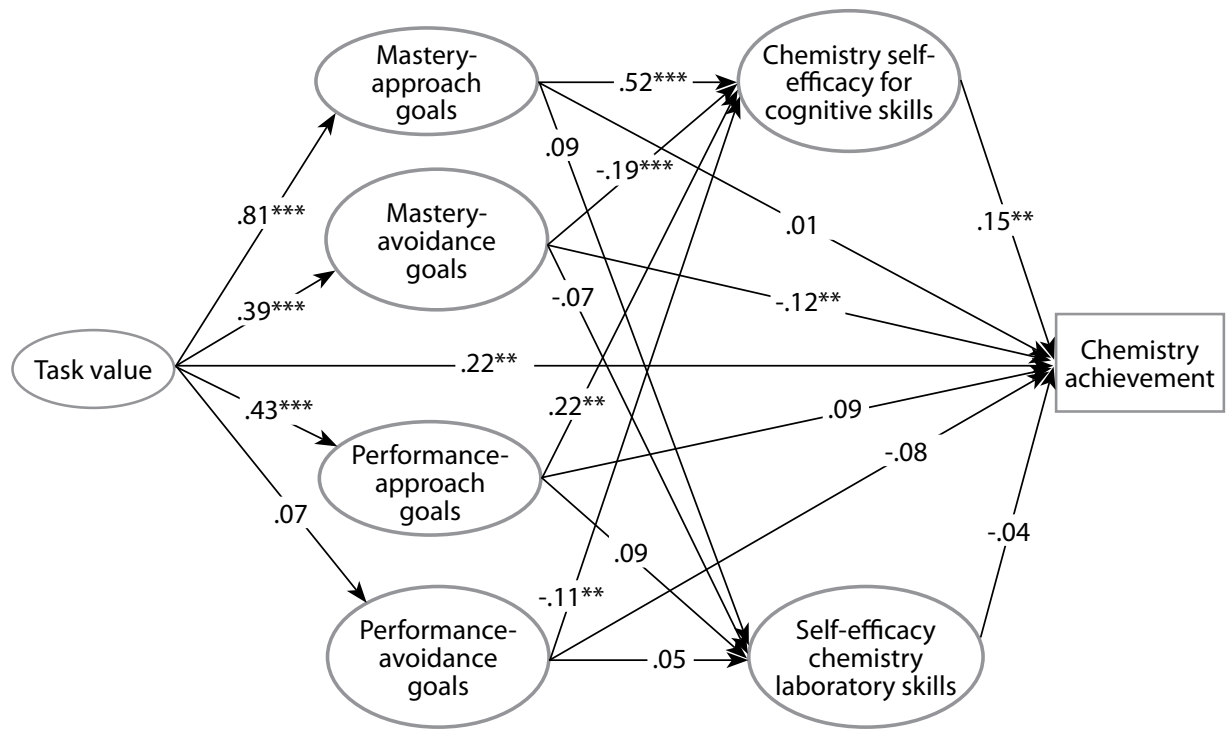

Figure 2. Standardized coefficients for the structural model of the relationship between task value, masteryapproach goals, mastery-avoidance goals, performance-approach goals, performance-avoidance goals, chemistry self-efficacy for cognitive skills, self-efficacy for chemistry laboratory, and chemistry achievement.

Note. For clarity of presentation, the indicator loadings are not presented. ${ }^{* * *} \mathrm{p}<<.001,{ }^{* * *} \mathrm{p}<.05$ 
Direct, indirect and total effects. Table 3 indicates the standardized direct, indirect, and total effects in the less-restricted model (partial mediation). In terms of Hypothesis 1, the findings indicated that task value was a significant positive predictor of mastery-approach goals $(g=.81)$, performance-approach goals $(g=.43)$, and mastery-avoidance goals $(\mathrm{g}=.30)$. While mastery-approach goals $(\mathrm{g}=.52)$ and performance-approach goals $(\mathrm{g}=.22)$ were found to be positive predictors of CSCS, mastery-avoidance goals ( $\mathrm{g}=-\mathrm{.11}$ ) was found to be a negative predictor (Hypothesis 2 ). Lastly, CSCS was a significant predictor of chemistry achievement ( $g=.15$, Hypothesis 3). Mastery-avoidance goals had a direct negative influence on chemistry achievement $(g=-.12)$. The direct influence of task value on chemistry achievement was found to be significant and positive ( $g=.22$ ). All the other loadings were non-significant.

Table 3

Standardized direct, indirect, and total effects in the less-restricted model (partial mediation)

\begin{tabular}{llccc}
\hline Predictor & Criterion & Direct Effect & $\begin{array}{c}\text { Indirect } \\
\text { Effect }\end{array}$ & Total Effect \\
\hline Task value & Mastery-approach goals & .81 & - & .81 \\
& Mastery-avoidance goals & .30 & - & .30 \\
& Performance-approach goals & .43 & - & .43 \\
& Performance-avoidance goals & .07 & - & .07 \\
& Chemistry achievement & .22 & .07 & .29 \\
Mastery-approach goals & CSCS & .52 & - & .52 \\
& SCL & .09 & - & .09 \\
& Chemistry achievement & .01 & .08 & .09 \\
Mastery-avoidance goals & CSCS & -.19 & - & -.19 \\
& SCL & -.07 & - & -.07 \\
& Chemistry achievement & -.12 & -.03 & -.15 \\
Performance-approach goals & CSCS & .22 & - & .22 \\
& SCL & .09 & - & .09 \\
& Chemistry achievement & .09 & .03 & .12 \\
Performance-avoidance goals & CSCS & & & -.11 \\
& SCL & -.11 & - & .05 \\
& CSCS & .05 & - & -.10 \\
SCL & Chemistry achievement & -.08 & -.02 & .15 \\
\hline & Chemistry achievement & .15 & - & -.04 \\
\hline
\end{tabular}

The indirect influence of goal orientations on chemistry achievement was through CSCS and SCL: While mastery-approach goals $(\mathrm{g}=.08)$ and performance-approach goals ( $\mathrm{g}=.03$ ) were found to be positively related to chemistry achievement, masteryavoidance goals $(\mathrm{g}=-.03)$ and performance-avoidance goals $(\mathrm{g}=-.02)$ were found to be negatively related to chemistry achievement (Hypothesis 4 ). Finally, task value was found to be related with chemistry achievement $(\mathrm{g}=.07)$ through the partial mediation 
of goal orientations and chemistry self-efficacy (Hypothesis 5). Overall, the predictor variables accounted for $14 \%$ of the variance in chemistry achievement.

\section{Discussion}

The purpose of the present study was to examine the relationships among task value, goal orientations, and self-efficacy in predicting $11^{\text {th }}$ grade students' chemistry achievement. SEM results provided support for the model with the significant contributions of task value on approach-oriented goals and mastery-avoidance goals, of approach-oriented goals and mastery-avoidance goals on CSCS, and of CSCS on chemistry achievement. In addition, there was a positive, significant, relationship between task value and chemistry achievement and negative significant relationship between mastery-avoidance goals and chemistry achievement.

Task value has been found to be a positive predictor of three types of goal orientations, mastery-approach goals, mastery-avoidance goals, and performanceapproach goals, with the highest contribution on mastery-approach goals. This suggests that students who find chemistry important and useful, tended to set goals to understand chemistry for their competence, to avoid failing in chemistry tasks, and to demonstrate their ability over others. In the related literature, mastery goals have been linked to high task values (Greene \& Miller, 1996; Greene et al., 2004; Lau et al., 2008; Liem et al., 2008; Rawsthorne \& Elliot, 1999).

In addition, task value positively predicted performance-approach goals which focus on the desire to outperform others. According to Greene et al. (2004), people perceive a task important because of either the possible use of the task in future or doing better than others. In the present study, students might value chemistry tasks because of both of these reasons, and thus, they might set performance-approach goals as well. In addition, in Turkey, high school students must take university entrance examination in order to attend colleges. In this exam, there are multiple-choice questions which assess knowledge and skills of students in a variety of topics such as mathematics, chemistry, physics, biology, history, and Turkish language and literature. Students' score on this exam along with their high school grade-point averages form the final score which is used for admission to a college (YÖK, 2000). Considering the large number of applicants who apply to take this exam each year, it is very competitive to earn high scores and continue college education after high school. In the present study, taking the role of chemistry course on the students' way to college into account, students might have high task value in chemistry and set performanceapproach goals to outperform others. Pintrich and Schunk (2007) suggested that students may set both mastery goals and performance-approach goals depending on the characteristics of context and their personality. On the other hand, task value was not found as a predictor of performance-avoidance goals. In fact, performanceavoidance goals have been expected to be negatively correlated with interest and task value (Pintrich \& Schunk, 2007). Adoption of goal orientations depends on 
personal, environmental and psychological factors (Elliot, 1999). Therefore, further research is warranted to examine the reasons underlying students' setting of goals. Moreover, task value was partially mediated by goal orientations and chemistry selfefficacy to predict chemistry achievement. This result supports the previous findings indicating significant relationship between task value and achievement (e.g., Bong, 2001; Yumusak et al., 2007).

Another finding of the present study was that approach-oriented goals predicted chemistry self-efficacy for cognitive skills. That is, students who focus on learning chemistry for their competence and for being better than others tended to have high chemistry self-efficacy beliefs for cognitive skills. These findings are consonant with the results of other research studies which pointed out a positive relationship between mastery-approach goals and self-efficacy (Dweck \& Leggett, 1988; Kaplan \& Midgley, 1997; Phan, 2009; Yi \& Hwang, 2003). Pintrich and Schunk (2007) suggest that students who are mastery oriented have a tendency to benefit from feedbacks for their improvement and thereby, develop efficacy beliefs. In literature, there have been inconsistent findings about the relationship between self-efficacy and performanceapproach goals. While researchers have not reported a significant relationship between performance-approach goals and self-efficacy for elementary students (Anderman \& Midgley, 1997); for high school students, performance-approach goals were associated with self-efficacy (Pajares et al., 2000; Skaalvik, 1997). Midgley (1993) stated that students in high schools are more performance-oriented than those in elementary schools. Therefore, the relationship found was not surprising. When Turkish high school classes are considered with the stress on university entrance examination, it is likely for students to be performance-oriented, interpret their success as comparing themselves with others, and develop self-efficacy beliefs.

Moreover, mastery-avoidance goals negatively predicted chemistry self-efficacy for cognitive skills. In other words, students who set goals avoiding failure in chemistry tasks tended to have low chemistry self-efficacy for cognitive skills. This result supports Elliot (1999) pointing out a negative relationship between mastery-avoidance goals and students' concern about their capabilities in a task. Chemistry is one of the important subjects to get a high score in university entrance examination in Turkey. In addition, it has been considered as a difficult subject by most students (Britner \& Pajares, 2006; Kennedy, 1996). Therefore, in the current study, students might set goals so as not to misunderstand and fail in chemistry topics. These students tended to have low chemistry self-efficacy for cognitive skills and in turn, low achievement.

Self-efficacy for chemistry laboratory, on the other hand, was not associated with any type of goal orientation in the present study, contrary to the hypothesis. The reason might be related to the structure of chemistry classes. Generally, chemistry classes in Turkey are based on teaching chemistry theoretically. Students do not have much experience with performing experiments, dealing with chemicals, using equipments, making necessary calculations, and interpreting the results of experiments 
in laboratories. This situation might be a reason why we could not find any relationship between goal orientations and self-efficacy for chemistry laboratory.

Finally, chemistry achievement was predicted by chemistry self-efficacy beliefs for cognitive skills. That is, the higher the students' beliefs in their ability to perform chemistry tasks successfully, the higher the achievement they have in chemistry. This finding added evidence to the literature on the relationship between self-efficacy and achievement (e.g. Britner \& Pajares, 2001; Kupermintz, 2002; Lau \& Roeser, 2002; Pintrich \& De Groot, 1990). Bandura (1986) proposed that people's beliefs about themselves influence their behavior, thoughts, and performance. For example, students with high self-efficacy beliefs in chemistry are likely to engage in activities related to chemistry, persist in face of difficulties, and become successful in the end. Indeed, Bandura considers self-efficacy beliefs as a better predictor of behavior than other variables such as prior knowledge. In the current study, therefore, the finding that indicated significant association between self-efficacy and achievement was not surprising. However, self-efficacy for chemistry laboratory did not predict chemistry achievement. The meager or no experience of Turkish students with laboratory work might be a reason for this finding. Overall, chemistry achievement was predicted by approach-oriented goals and mastery-avoidance goals through chemistry self-efficacy for cognitive skills. This means that students who set their goals to develop their competence and outperform others tended to be successful in $11^{\text {th }}$ grade chemistry, owing to high chemistry self-efficacy beliefs in cognitive skills. However, students who set mastery-avoidance goals were likely to have low achievement level in chemistry due to their low self-efficacy.

It should be noted that there are several limitations to the present study. Firstly, this study is correlational, therefore, we cannot make any inferences about causal relations. Experimental studies are warranted to examine cause-and-effect relationship among variables. Secondly, the variables in the study may be reciprocally related to each other, which should be tested in further studies. Thirdly, in the current study, $11^{\text {th }}$ grade chemistry was taken as a context. Further studies may investigate the relationship among variables in different subject domains and grade levels. Fourthly, self-report instruments were used in the current study, assuming that students would give sincere responses. Further research utilizing different sources of data (e.g., observation) might be carried out to increase validity of real life behavior and decrease common method variance. Lastly, we tried to predict students' chemistry achievement through task value, goal orientations, and self-efficacy. Further research may investigate the relationship between chemistry achievement and other variables, such as selfregulation, and learning strategies.

\section{Practical Implications}

In spite of the limitations, the findings of the present study add knowledge to the existing body of literature and practice by indicating the interplay between task value, 
goal orientations, and chemistry self-efficacy in predicting chemistry achievement. In particular, because of abstract and complex nature of chemistry, most students consider chemistry as a difficult subject and perform poorly (Britner \& Pajares, 2006; Kennedy, 1996). The results of this study might be helpful for teachers to increase student achievement. For example, teachers should highlight the importance of chemistry in daily life during their instruction. They should provide students with opportunities to engage in more chemistry activities, to realize their past successful experiences with chemistry tasks, and encourage them to believe in their ability to accomplish chemistry tasks. Having high level of self-efficacy and valuing chemistry tasks may bring high level of achievement. In addition, students should be encouraged to set goals which best fit the context and their personal characteristics and purposes, leading to success. Overall, teachers may design instructions to promote students' understanding of chemistry tasks, considering the variables and their associations suggested in the current study.

\section{References}

Ames, C. (1992). Classrooms: Goals, structures, and student motivation. Journal of Educational Psychology, 84, 261-271. http://dx.doi.org/10.1037/0022-0663.84.3.261

Anderman, E. M., \& Maehr, M. L. (1994). Motivation and schooling in the middle grades. Review of Educational Research, 64, 287-309. http://dx.doi.org/10.3102/00346543064002287

Anderman, E. M., \& Midgley, C. (1997). Changes in achievement goal orientations, perceived academic competence, and grades across the transition to middle-level schools. Contemporary Educational Psychology, 22, 269-298. http://dx.doi.org/10.1006/ ceps. 1996.0926

Arbuckle, J. L., \& Wothke, W. (2006). Amos 7.0 User's Guide. Chicago: SPSS.

Bandura, A. (1986). Social foundations of thought and action: A social cognitive theory. Englewood Cliffs, NJ: Prentice Hall.

Bong, M. (2001). Role of self-efficacy and task-value in predicting college students' course performance and future enrollment intentions. Contemporary Educational Psychology, 26, 553-570. http://dx.doi.org/10.1006/ceps.2000.1048

Britner, S. L. (2008). Motivation in high school science students: A comparison of gender differences in life, physical, and earth science classes. Journal of Research in Science Teaching, 45, 955-970. http://dx.doi.org/10.1002/tea.20249

Britner, S. L., \& Pajares, F. (2001). Self-efficacy beliefs, motivation, race, and gender in middle school science. Journal of Women and Minorities in Science and Engineering, 7, 271-285.

Britner, S. L., \& Pajares, F. (2006). Sources of science self-efficacy beliefs in middle school students. Journal of Research in Science Teaching, 43, 485-499. http://dx.doi.org/10.1002/ tea.20131 
Browne, M. W., \& Cudeck, R. (1993). Alternative ways of assessing model fit. In K. A. Bollen \& J. S. Long (Eds.), Testing structural equation models (pp. 136-162). Newbury Park, CA: Sage.

Byrne, B. M. (2001). Structural equation modeling with AMOS. Mahwah, NJ: Lawrence Erlbaum.

Capa Aydin, Y., \& Uzuntiryaki, E. (2009). Development and psychometric evaluation of the high school chemistry self-efficacy scale. Educational and Psychological Measurement, 69, 868-880. http://dx.doi.org/10.1177/0013164409332213

Cavallo, A. M. L., Potter, W. H., \& Rozman, M. (2004). Gender differences in learning constructs, shifts in learning constructs, and their relationship to course achievement in a structured inquiry, yearlong college physics course for life science majors. School Science and Mathematics, 104, 288-300. http://dx.doi.org/10.1111/j.1949-8594.2004.tb18000.x

Dweck, C. (1986) Motivation processes affecting learning. American Psychologist, 41, 10401048. http://dx.doi.org/10.1037/0003-066X.41.10.1040

Dweck, C. S., \& Leggett, E. L. (1988). A social cognitive approach to motivation and personality. Psychological Review, 95, 256-273. http://dx.doi.org/10.1037/0033295X.95.2.256

Eccles J. S., Adler, T. F., Futterman, R., Goff, S. B., Kaczala, C. M., Meece, J. L., \& Midgley, C. (1983). Expectancies, values, and academic behaviors. In J. T. Spence (Ed.), Achievement and achievement motivation (pp. 75-146). San Francisco, CA: W. H. Freeman.

Eccles, J. S., \& Wigfield, A. (1995). In the mind of the actor: The structure of adolescents' achievement task values and expectancy-related beliefs. Personality and Social Psychology Bulletin, 21, 215-225. http://dx.doi.org/10.1177/0146167295213003

Elliot, A. J. (1997). Integrating the 'classic' and 'contemporary' approaches to achievement motivation: A hierarchical model of approach and avoidance achievement motivation. In M. L. Maehr \& P. R. Pintrich (Eds.), Advances in motivation and achievement, vol. 10 (pp. 143- 179). Greenwich, Connecticut: JAI.

Elliot, A. J. (1999). Approach and avoidance motivation and achievement goals. Educational Psychologist, 34, 169-189. http://dx.doi.org/10.1207/s15326985ep3403_3

Elliot, A. J., \& Harackiewicz, J. M. (1996). Approach and avoidance achievement goals and intrinsic motivation: A mediational analysis. Journal of Personality and Social Psychology, 70, 461-475. http://dx.doi.org/10.1037/0022-3514.70.3.461

Elliot, A.J., \& McGregor, H.A. (1999). Test anxiety and the hierarchical model of approach and avoidance achievement motivation. Journal of Personality and Social Psychology, 76, 628-644. http://dx.doi.org/10.1037/0022-3514.76.4.628

Elliot, A. J., \& McGregor, H. (2001). A $2 \times 2$ achievement goal framework. Journal of Personality and Social Psychology, 80, 501-519. http://dx.doi.org/10.1037/0022-3514.80.3.501

Fenollar, P., Román, S., \& Cuestas, P. J. (2007). University students' academic performance: An integrative conceptual framework and empirical analysis. British Journal of Educational Psychology, 77, 873-891. http://dx.doi.org/10.1348/000709907X189118

Greene, B. A., \& Miller, R. B. (1996). Influences on course performance: Goals, perceived ability, and self-regulation. Contemporary Educational Psychology, 21, 181-192. http:// dx.doi.org/10.1006/ceps.1996.0015 
Greene, B. A., Miller, R. B., Crowson, H. M., Duke, B. L., \& Akey, K. L. (2004). Predicting high school students' cognitive engagement and achievement: Contributions of classroom perceptions and motivation. Contemporary Educational Psychology, 29, 462-482. http:// dx.doi.org/10.1016/j.cedpsych.2004.01.006

Hampton, N. Z., \& Mason, E. (2003). Learning disabilities, gender, sources of self-efficacy, self-efficacy beliefs, and academic achievement in high school students. Journal of School Psychology, 41, 101-112. http://dx.doi.org/10.1016/S0022-4405(03)00028-1

Hu, L., \& Bentler, P. M. (1999). Cutoff criteria for fit indices in covariance structure analysis: conventional criteria versus new alternatives. Structural Equation Modeling, 6, 1-55. http:// dx.doi.org/10.1080/10705519909540118

Kaplan, A., \& Maehr, M. L. (1999). Achievement goals and student well-being. Contemporary Educational Psychology, 24, 330-358. http://dx.doi.org/10.1006/ceps.1999.0993

Kaplan, A., \& Midgley, C. (1997). The Effect of Achievement Goals: Does Level of Perceived Academic Competence Make a Difference? Contemporary Educational Psychology, 22, 415435. http://dx.doi.org/10.1006/ceps.1997.0943

Kennedy, E. (1996). What do they think of chemistry? Australian Science Teachers Journal, 42(2), 53-59.

Kline, R. B. (1998). Principles and practice of structural equation modeling. New York: Guilford.

Kupermintz, H. (2002). Affective and conative factors as aptitude resources in high school science achievement. Educational Assessment, 8(2), 123-137. http://dx.doi.org/10.1207/ S15326977EA0802_03

Lau, S., \& Roeser, R. W. (2002). Cognitive abilities and motivational processes in high school students' situational engagement and achievement in science. Educational Assessment, 8, 139-162.http://dx.doi.org/10.1207/S15326977EA0802_04

Lau, S., Liem, A. D., \& Nie, Y. (2008). Task- and self-related pathways to deep learning: The mediating role of achievement goals, classroom attentiveness, and group participation. British Journal of Educational Psychology, 78, 639-662. http://dx.doi. org/10.1348/000709907X270261

Liem, A. D., Lau, S., \& Nie, Y. (2008). The role of self-efficacy, task value, and achievement goals in predicting learning strategies, task disengagement, peer relationship, and achievement outcome. Contemporary Educational Psychology, 33, 486-512. http://dx.doi. org/10.1016/j.cedpsych.2007.08.001

Middleton, M. J., \& Midgley, C. (1997). Avoiding the demonstration of lack of ability: An under-explored aspect of goal theory. Journal of Educational Psychology, 89, 710-718. http://dx.doi.org/10.1037/0022-0663.89.4.710

Midgley, C. (1993). Motivation and middle level schools. In P. Pintrich \& M. L. Maehr (Eds.), Advances in motivation and achievement: Motivation in the adolescent years. Vol. 8. (pp. 219276). Greenwich, CT: JAI Press.

Miller, R. B., \& Brickman, S. A. (2004). A model of future oriented motivation and selfregulation. Educational Psychology Review, 16, 9-33. http://dx.doi.org/10.1023/ B:EDPR.0000012343.96370.39

Pajares, F., Britner, S.L., \& Valiante, G. (2000). Relation between achievement goals and self-beliefs of middle school students in writing and science. Contemporary Educational Psychology, 25, 406-422. http://dx.doi.org/10.1006/ceps.1999.1027 
Pajares, F., \& Miller, M. D. (1994). The role of self-efficacy and self-concept beliefs in mathematical problem-solving: A path analysis. Journal of Educational Psychology, 86, 193-203. http://dx.doi.org/10.1037/0022-0663.86.2.193

Phan, P. H. (2009). Relations between goals, self-efficacy, critical thinking and deep processing strategies: a path analysis. Educational Psychology, 29, 777-799. http://dx.doi. org/10.1080/01443410903289423

Pintrich, P. R., \& De Groot, E. V. (1990). Motivational and self-regulated learning components of classroom academic performance. Journal of Educational Psychology, 82, 33-40. http:// dx.doi.org/10.1037/0022-0663.82.1.33

Pintrich, P. R., \& Schunk, D. H. (2007). Motivation in education: Theory, research, and applications. Upper Saddle River, N.J.: Prentice Hall.

Pintrich, P. R., Smith, D. A. F., Garcia, T., \& Mckeachie, W. J. (1991). A manual for the use of the Motivated Strategies for Learning Questionnaire (MSLQ). Ann Arbor, MI: National Center for Research to Improve Postsecondary Teaching and Learning, University of Michigan.

Rawsthorne, L.J., \& Elliot, A.J. (1999). Achievement goals and intrinsic motivation: A meta-analytic review. Personality and Social Psychology Review, 3, 326-344. http://dx.doi. org/10.1207/s15327957pspr0304_3

Senler, B., \& Sungur, S. (2007). Hedef yönelimi anketinin Türkçe’ye çevrilmesi ve adaptasyonu [Adaptation of achievement goal questionnaire into Turkish], 1. Ulusal İlköğretim Kongresi [Abstracts of the I. National Elementary Education Conference]. Ankara: Pegem Academy Publication, 18.

Skaalvik, E. M. (1997). Self-enhancing and self-defeating ego orientation: Relations with task and avoidance orientation, achievement, self-perceptions, and anxiety. Journal of Educational Psychology, 89, 71-81. http://dx.doi.org/10.1037/0022-0663.89.1.71

Sungur, S. (2004). The implementation of problem based learning in high school biology courses. (Doctoral dissertation). Ankara: Faculty of Education Middle East Technical University in Ankara.

Sungur, S. (2007). Modeling the relationships among students' motivational beliefs, metacognitive strategy use, and effort regulation. Scandinavian Journal of Educational Research, 51, 315-326. http://dx.doi.org/10.1080/00313830701356166

Tanaka, A. \& Yamauchi, H. (2001). A model for achievement motives, goal orientations, intrinsic interest, and academic achievement. Psychological Reports, 88, 123-135. http:// dx.doi.org/10.2466/pr0.2001.88.1.123

Ullman, J. B. (2007). Structural equation modeling. In B. G. Tabachnick \& L. S. Fidell (Eds.), Using multivariate statistic (pp. 676-780). Boston: Pearson.

Urdan, T., Ryan, A. M., Anderman, E. M., \& Gheen, M. H. (2002). Goals, goal structures, and avoidance behaviors. In C. Midgley (Ed.), Goals, goal structures and patterns of adaptive learning (pp. 55- 83). Mahwah, New Jersey: Erlbaum.

Utman, C. H. (1997). Performance effects of motivational states: A meta-analysis. Personality and Social Psychology Review, 1, 170-182. http://dx.doi.org/10.1207/s15327957pspr0102_4

Uzuntiryaki, E., \& Capa Aydin, Y. (2009). Development and validation of chemistry selfefficacy scale for college students. Research in Science Education, 39, 539-551. http://dx.doi. org/10.1007/s11165-008-9093-x 
Wigfield, A. (1994). Expectancy-value theory of achievement motivation: A developmental perspective. Educational Psychology Review, 6, 49-78. http://dx.doi.org/10.1007/ BF02209024

Wigfield, A., \& Eccles, J. S. (1992). The development of achievement task values: A theoretical analysis. Developmental Review, 12, 265-310. http://dx.doi.org/10.1016/02732297(92)90011-P

Wolters, C. A., Yu, S. L., \& Pintrich, P. R. (1996). The relation between goal orientation and students' motivational beliefs and self-regulated learning. Learning and Individual Differences, 8, 211-238. http://dx.doi.org/10.1016/S1041-6080(96)90015-1

Yi, M. Y., \& Hwang, Y. (2003). Predicting the use of web-based information systems: selfefficacy, enjoyment, learning goal orientation, and the technology acceptance model. International Journal of Human-Computer Studies, 59, 431-449. http://dx.doi.org/10.1016/ S1071-5819(03)00114-9

YÖK, (2000). Student Selection and Placement System /online/. Retrieved on 12th December 2013 from http://www.yok.gov.tr/content/view/795/194/lang,tr/

Yuan, K. H., \& Bentler, P. M. (2004). On chi-square difference and z-tests in mean and covariance structure analysis when the base model is misspecified. Educational and Psychological Measurement, 64, 737-757. http://dx.doi.org/10.1177/0013164404264853

Yumusak, N., Sungur, S., \& Cakiroglu, J. (2007). Turkish high school students' biology achievement in relation to academic self-regulation. Educational Research and Evaluation, 13, 53-69. http://dx.doi.org/10.1080/13803610600853749

\title{
Esen Uzuntiryaki-Kondakci
}

Middle East Technical University

Üniversiteler Mahallesi,

Dumlupınar Bulvarı No:1

06800 Çankaya Ankara, Turkey

esent@metu.edu.tr

\author{
Ayse Senay \\ Middle East Technical University \\ Üniversiteler Mahallesi, \\ Dumlupınar Bulvarı No:1 \\ 06800 Çankaya Ankara, Turkey \\ aysehoca@gmail.com
}




\section{Predviđanje postignuća u kemiji putem vrijednosti zadatka, usmjerenosti cilju i samoučinkovitosti: strukturalni model}

\section{Sažetak}

Svrha ovoga istraživanja bila je istražiti odnose između vrijednosti zadatka, usmjerenosti cilju i samoučinkovitosti u kemiji kod predviđanja uspjeha učenika jedanaestoga razreda za predmet Kemija u Turskoj. Ukupno su u istraživanju sudjelovala 572 učenika jedanaestog razreda koji su imali predmet Kemija. Podaci su prikupljeni koristeći se upitnikom Motivacijske strategije učenja, upitnikom Ostvarenje cilja, Skalom samoučinkovitosti za kemiju, i Testom postignuća iz kemije. Rezultati strukturalnog modeliranja ukazali su na to da je vrijednost zadatka značajan, pozitivan, prediktor cilja ovladavanja uključivanjem, cilja izvedbe uključivanjem i cilja ovladavanja izbjegavanjem. Cilj ovladavanja uključivanjem $i$ cilj izvedbe uključivanjem pozitivni su prediktori za samoučinkovitost iz kemije za kognitivne vještina, a cilj ovladavanja izbjegavanjem negativan je prediktor samoučinkovitosti iz kemije za kognitivne vještine. Na kraju, samoučinkovitost u kemiji za kognitivne vještine značajan je prediktor postignuća iz kemije. U cjelini, rezultati istraživanja proširuju postojeću literaturu vezanu uz međusobni utjecaj vrijednosti zadatka, usmjerenosti cilju, samoučinkovitosti kod predviđanja postignuća iz kemije.

Ključne riječi: postignuće iz kemije; samoučinkovitost; strukturalno modeliranje; usmjerenost cilju; vrijednost zadatka.

\section{Uvod}

Već više od dva desetljeća povećava se opseg literature koja proučava međuodnose motivacijskih varijabli kako bi se predvidjelo postignuće. Većina istraživanja ukazuje na značajnu ulogu vrijednosti zadatka, usmjerenosti cilju i samoučinkovitost kod postignuća (npr., Elliot i McGregor, 1999; Hampton i Mason, 2003; Kaplan i Maehr, 1999; Pajares i Miller, 1994; Phan, 2009; Pintrich i Schunk, 2007; Wigfield, 1994). 
Proučavanje međusobnih utjecaja tih varijabli u integriranom okviru važno je za razumijevanje prirode motivacijskih faktora, prepoznavanje odlučujućih i medijacijskih uloga tih varijabli u predviđanju izvedbe, i s druge strane za razvijanje strategija za poboljšanje postignuća učenika. Shodno tome, svrha ovoga istraživanja bila je proučiti odnose između vrijednosti zadatka, usmjerenosti cilju i samoučinkovitosti kod predviđanja postignuća turskih učenika jedanaestoga razreda iz kemije. Niže su objašnjeni teorijski okviri za motivacijske konstrukte korištene $u$ istraživanju.

Vrijednost zadatka proučavanja je iz gledišta teorije očekivane korisnosti. Ta teorija pretpostavlja da je postignuće predmet motiva, očekivanja uspješnosti i vrijednosti. Drugim riječima, dispozicija pojedinaca na uspjeh, njihova subjektivna vjerovanja o vjerojatnosti uspjeha u nekom budućem zadatku u budućnosti i vrijednost koju pripisuju zadatku utječu na njihovu izvedbu (Atkinson 1957, prema Wigfield i Eccles, 1992). U ovome trenutku u teoriji očekivane korisnosti, Eccles i sur. (1983), vrijednost zadatka promatra se kroz četiri elementa: (a) vrijednost postignuća: važnost zadatka za pojedinca, (b) intrinzična vrijednost: zadovoljstvo pojedinca u radu na zadatku, (c) korisnost: korisnost zadatka da zadovolji daljnje ciljeve i (d) trošak: posljedice upuštanja u zadatak. Eccles i Wigfield (1995) tvrde da ako neki zadatak ima potencijal udovoljiti potrebama osobe i potaknuti ostvarenje ciljeva i ako zadatak potvrđuje njegove osobne vrijednosti, onda osoba ima tendenciju davanja vrijednosti tome zadatku i uključivanje u zadatak. Nedavna istraživanja također su naglasila važnost vrijednosti zadatka u predviđanju postignuća (Bong, 2001; Pintrich i Schunk, 2007; Yumusak i sur., 2007). Međutim, još se uvijek postavlja pitanje vrednuje li pojedinac zadatak za koji je kompetentan ili razvije vrijednost o zadatku kao rezultat kompetencije (Pintrich i Schunk, 2007). U ovom istraživanju pokušat će razjasniti ulogu vrijednosti zadatka na postignuće uzimajući u obzir usmjerenost cilju i samoučinkovitost.

Usmjerenost cilju podrazumijeva „različite načine u pristupanju, angažmanu i reakciji na aktivnosti vezane uz postignuće" (Ames, 1992, str. 261), i stoga utječe na postignuće. Usmjerenost cilju definira se kao razlozi zašto i kako pojedinci teže ostvarenju svojih ciljeva (Ames, 1992; Anderman i Maehr, 1994). Rana istraživanja usmjerenosti cilju predlagala su dihotomni model s dvije primarne vrste ciljeva kao cilj ovladavanja zadatkom i cilj izvedbe (Ames, 1992; Dweck, 1986), i trihotomni model koji podrazumijeva cilj ovladavanja zadatkom, motivaciju uključivanja i motivaciju izbjegavanja ostvarenja cilja (Elliot, 1997; Elliot i Harackiewicz, 1996). U posljednje vrijeme istraživači su proširili model koncipirajući četvrti cilj postignuća, tj. cilj ovladavanja zadatkom putem izbjegavanja, $\mathrm{u} 2 \times 2$ modelu ciljeva postignuća (Elliot $\mathrm{i}$ McGregor, 2001). U ovome istraživanju korišten je $2 \times 2$ model kako bi se identificirale usmjerenosti učenika na cilj.

Studenti kojima je cilj ovladavanje zadatkom putem uključivanja zapravo ciljaju na osobni razvoj. Suprotno tome, ciljevi ovladavanja zadatkom putem izbjegavanja povezani su s izbjegavanjem neuspjeha u nastojanju da se dosegne određena razina ili riješi zadatak. Cilj izvedbe povezan je s nastojanjima studenata da nadmaše ostale, 
a cilj ovladavanja zadatkom putem izbjegavanja podrazumijeva nastojanje da se izbjegne neuspjeh u odnosu na ostale studente (Elliot, 1997; Elliot i Harackiewicz, 1996). Općenito gledano, istraživanja su ukazala na postojanje povezanosti između ciljeva ovladavanja zadatkom i pozitivnih ishoda poput ustrajnosti, visoke razine samoučinkovitosti i visokih ocjena (Elliot i McGregor, 1999; Kaplan i Maehr, 1999; Phan, 2009; Tanaka i Yamauchi, 2001; Utman, 1997). Za razliku od toga cilj ovladavanja zadatkom putem izbjegavanja povezano je s niskim razinama samoučinkovitosti, visokom anksioznošću i lošim uspjehom na testovima (Elliot, 1999; Elliot i McGregor, 1999; Urdan i sur., 2002). Elliot (1999) naglašava da učenikov odabir određene vrste cilja ovisi o psihološkim i okolišnim faktorima.

Samoučinkovitost, središnji konstrukt socijalno-kognitivne teorije, definirana je kao „procjena ljudi o vlastitim sposobnostima da organiziraju i ishode djelovanja potrebna kako bi ostvarili određene vrste izvedbe“ (Bandura, 1986, str. 391). Bandura je vjerovanja o samoučinkovitosti okarakterizirao kao specifična za zadatak i za domenu. Učenici mogu imati različite procjene samoučinkovitosti u različitim domenama ili zadacima. Primjerice, učenik koji osjeća učinkovitost $\mathrm{u}$ kemiji, možda ne osjeti isto $\mathrm{u}$ matematici. Prema tome, vjerovanja učenika u samoučinkovitost moraju se istražiti u specifičnim domenama. $\mathrm{U}$ ovome istraživanju bavili smo se samoučinkovitošću u kontekstu kemije. U skladu s Bandurinom definicijom, samoučinkovitost u kemiji može se opisati kao vjerovanje učenika u vlastite sposobnosti da uspješno riješe određene zadatke iz kemije (Uzuntiryaki i Capa Aydin, 2009). Socijalno-kognitivna teorija podrazumijeva da vjerovanje pojedinca utječe na njegove misli, ponašanja i djelovanje. Prema tome, očekuje se da samoučinkovitost ima ključnu ulogu u odabiru aktivnosti vezane uz znanost, u nastojanjima, ukazivanju na ustrajnost, i u uspješnom rješavanju zadataka. Naravno, mnoga su istraživanja pokazala da je samoučinkovitost najpouzdaniji prediktor učenikovih postignuća (Britner, 2008; Britner i Pajares, 2006; Cavallo i sur., 2004; Lau i Roeser, 2002; Pintrich i De Groot, 1990).

\section{Istraživanje}

Svrha ovoga istraživanja bila je istražiti odnos između vrijednosti zadatka, usmjerenosti cilju i samoučinkovitosti u predviđanju postignuća učenika jedanaestog razreda iz Kemije. Vrijednost zadatka bila je polazišna točka ovoga istraživanja, uzimajući u obzir ulogu vrijednosti zadatka u postignuću na koje upućuju i teorija (Eccles i sur., 1983) i empirijska istraživanja (Pintrich i Schunk, 2007; Yumusak i sur., 2007). Nadalje, Miller i Brickman (2004) tvrde da kada pojedinci procijene zadatak kao vrijedan za učenje, tada postavljaju i ciljeve postignuća. Drugi istraživači također naglašavaju predvidivu ulogu vrijednosti zadatka na usvajanje ciljeva (Greene i sur., 2004; Liem i sur., 2008; Sungur, 2007). Uzimajući u obzir te odnose, postavili smo vrijednost zadatka kao prediktor orijentacija ciljeva u modelu koji smo predložili.

Rezultati istraživanja pokazali su nedosljednosti u odnosu između orijentacija cilja i samoučinkovitosti. Dok neka istraživanja (Fenollar i sur., 2007; Greene i sur., 
2004; Liem i sur., 2008) ukazuju na to da je samoučinkovitosti prediktor ciljeva postignuća, druga istraživanja ukazuju na to da su ciljevi postignuća značajan prediktor za samoučinkovitost (Middleton i Midgley, 1997; Pajares i sur., 2000; Phan, 2009; Yi i Hwang, 2003). Dweck i Leggett (1988) tvrde da učenici s orijentacijom cilja ovladavanja imaju pozitivnu afektivnu i intrinzičnu motivaciju kada su suočeni s izazovima. Ti učenici imaju tendenciju uživati u učenju novih izazovnih ideja i razvijanju samoučinkovitosti. Štoviše, Pintrich i Schunk (2007) smatrali su da će učenici s ciljem ovladavanja po svojoj vjerojatnosti procijeniti i povratnu informaciju kako bi pratili svoj napredak i tako razviti vjerovanja o samoučinkovitosti. Kod učenika srednjih škola ciljevi izvedbe bili su povezani sa samoučinkovitošću (Skaalvik, 1997; Wolters i sur., 1996). Prema tome, u ovome istraživanju ciljeve ovladavanja postavljamo kao prediktore za samoučinkovitost u kemiji. Na kraju, samoučinkovitost iz kemije postavljena je kao prediktor uzimajući u obzir i teoriju (Bandura, 1986) i rezultate empirijskih istraživanja (npr., Britner i Pajares, 2006; Lau i Roeser, 2002). Kao rezultat toga, postavljene su sljedeće hipoteze:

Hipoteza 1. Vrijednost zadatka bit će pozitivan prediktor za orijentacije cilja (tj. cilj ovladavanja uključivanjem, cilj ovladavanja izbjegavanjem, cilj izvedbe uključivanjem i cilj izvedbe izbjegavanjem).

Hipoteza 2. Orijentacije ciljeva bit će pozitivan prediktor samoučinkovitosti u kemiji (tj. samoučinkovitost u kemiji za kognitivne vještine i samoučinkovitost u kemijskom laboratoriju).

Hipoteza 3. Samoučinkovitost u kemiji bit će pozitivan prediktor postignuća u kemiji.

Hipoteza 4. Odnos između orijentacije cilja i postignuća u kemiji bit će posredovan samoučinkovitošću u kemiji.

Hipoteza 5. Odnos između vrijednosti zadatka i postignuća u kemiji bit će posredovan orijentacijom cilja i samoučinkovitošću u kemiji.

Slika 1 prikazuje ponuđeni model istraživanja.

Slika 1.

\section{Metode}

\section{Uzorak}

Uzorak u ovome istraživanju čine 572 učenika jedanaestog razreda (323 učenice i 249 učenika) koji su uključeni u nastavu kemije iz sedam različitih državnih škola u Ankari, u Turskoj. Srednja vrijednost učenika bila je 17,03 (SD =0,33). Sudjelovanje $\mathrm{u}$ istraživanju bilo je dobrovoljno. Učenici su bili obaviješteni o istraživanju te su dobili upute za rješavanje zadataka u instrumentima. Od njih se tražilo da surađuju s istraživačima na način da budu iskreni u odgovorima i u testovima, a njihovi odgovori bili bi povjerljivi te ne bi utjecali na njihovu ocjenu ni u kojem obliku. Za popunjavanje upitnika bilo je potrebno otprilike 50 minuta. 


\section{Instrumenti}

Četiri instrumenta korištena su za prikupljanje podataka:

Vrijednost zadatka. Vrijednost zadatka poddimenzija je Upitnika Motivacijska strategija učenja (MSLQ; Pintrich i sur., 1991) koji je korišten kako bi se identificirale percepcije učenika o važnosti kemije. Skalu je turskom jeziku prilagodio Sungur (2004). MSLQ se uvelike koristi u literaturi u cijelosti ili izdvajanjem podskala s ciljem istraživanja. U ovome istraživanju poddimenzija vrijednost zadatka korištena je za kontekst kemije. Sadrži 6 čestica s bodovnom skalom od 7 stupnjeva od 1 (uopće mi ne odgovara) do 7 (potpuno mi odgovara). Primjer čestice je "Meni je važno učiti sadržaj ovoga predmeta." Cronbach alpha procjena pouzdanosti bila je ,089.

Upitnik o cilju postignuća. Razvili su ga Elliot i McGregor (2001) kako bi istražili zašto i kako učenici sudjeluju u aktivnosti učenja. Sastoji se od četiri dimenzije: cilj ovladavanja uključivanjem, cilj ovladavanja izbjegavanjem, cilj izvedbe uključivanjem i cilj izvedbe izbjegavanjem. Instrument je upitnik koji sadrži 15 čestica na skali od 5 stupnjeva: 1 (nikada), 5 (uvijek). Instrument su na turski prilagodili Senler i Sungur (2007). Primjeri čestica su: "Želim u potpunosti ovladati materijalom koji je predviđen za ovaj razred, “"Brinem se da možda neću naučiti sve što bih mogao u ovome razredu," "Važno mi je da budem bolji od ostalih učenika” i „Samo želim izbjeći loš uspjeh u ovome razredu u odnosu na druge. "Cronbach alpha procjena pouzdanosti bila je 0,79 za cilj ovladavanja, 0,76 za cilj ovladavanja izbjegavanjem, 0,77 za cilj izvedbe uključivanjem i 0,78 za cilj izvedbe izbjegavanjem.

Skala samoučinkovitosti za kemiju (CSES). Razvili su ju Capa Aydin i Uzuntiryaki (2009) kako bi procijenili vjerovanja učenika srednjih škola u vlastitu sposobnost za izvođenje zadataka iz kemije. Skala se sastoji od 16 čestica koje pokrivaju dvije dimenzije: samoučinkovitost u kemiji za kognitivne vještine (CSCS) i samoučinkovitost za kemijski laboratorij (SCL). Učenici su trebali procijeniti svoja vjerovanja na skali od 9 stupnjeva: 1 (vrlo slabo), 9 (jako dobro). Primjer čestice bio je: „U kojoj mjeri možeš opisati strukturu atoma?" $i$,Koliko dobro možeš koristiti pribor u laboratoriju za kemiju?"“ Cronbach alpha procjena pouzdanosti bila je 0,83 za CSCS i 0,95 za SCL.

Test postignuća iz kemije (CAT). Test je razvijen kako bi istraživači provjerili znanje učenika iz kemije u jedanaestom razredu s obzirom na kurikul Ministarstva nacionalnog obrazovanja za kemiju i udžbenike iz kemije. Test se sastojao od 33 pitanja višestrukog izbora vezanim uz sljedeće teme: brzina kemijske reakcije, kemijska ravnoteža, ravnoteža topivosti, kiseline i baze, i elektrokemija. Uz pitanja vezana uz razinu znanja test je također uključivao čestice koje su nalagale vještinu više razine poput aplikacije i sinteze. Svaka je čestica u testu provjerena od četiri stručnjaka iz područja poučavanja kemije i predložene su promjene vezane uz valjanost sadržaja testa prihvaćene. Prije testiranja provedeno je probno testiranje kako bi se analizirale čestice testa te provjerio koeficijent pouzdanosti. Nakon izmjena koeficijent pouzdanosti testa bio je 0,88 . 


\section{Analiza podataka}

Strukturalno modeliranje (SEM) putem Analize struktura (AMOS) 7.0 (Arbuckle i Wothke, 2006) korišteno je kako bi se testirao ponuđeni model. SEM je statistička metoda korištena za proučavanje odnosa među skupinom nezavisnih i zavisnih varijabli (Ullman, 2007). Nezavisne varijable u ovome istraživanju su vrijednost zadatka, orijentacije ciljeva i samoučinkovitost u kemiji. Postignuće učenika u kemiji bila je zavisna varijabla. Prije SEM analize za predloženi konceptualni model, napravili smo potvrdnu faktorsku analizu (CFA) kako bismo testirali faktorsku strukturu modela za mjerenje. Nenormirani indeks slaganja (NNFI), komparativni indeks slaganja (CFI) i korijen srednje kvadratne pogreške aproksimacije (eng. Root Mean Square Error of Approximation, RMSEA) s 90\% intervalima pouzdanosti korišteni su uz hi-kvadrat $\left(\mathrm{c}^{2}\right)$ statistiku, s obzirom na to da se $\mathrm{c}^{2}$ smatra nepouzdanim (Byrne, 2001). Vrijednosti veće od 0,90 ukazuju na pogodan model slaganja (Kline, 1998), međutim, poželjne su vrijednosti veće od 0,95 (Hu i Bentler, 1999). Browne i Cudeck (1993) predlažu da RMSEA vrijednost bude manja od 0,05 što upućuje na blisko slaganje s modelom. Vrijednost između 0,05 i 0,08 upućuje na osrednje slaganje, a vrijednost veća od 0,10 upućuje na slabo slaganje. Nakon što smo osigurali da mjerni model ima pogodno slaganje, istražili smo konceptualni model. Nadalje, hikvadrat test razlika (Yuan i Bentler, 2004) korištena je kako bi se usporedila potpuna i parcijalna medijacija. Rezultati navedenih analiza prikazani su u dijelu Rezultati.

\section{Rezultati}

\section{Deskriptivna statistika}

Srednja vrijednost, standardna devijacija i korelacija između varijabli prikazani su u tablici 1. Čini se da je postignuće u kemiji povezano s vrijednošću zadatka, ciljevima ovladavanja uključivanjem, ciljevima izvedbe putem uključivanja i CSCS, dok nije povezano sa SCL, ciljevima ovladavanjem izbjegavanjem i ciljevima izvedbe putem izbjegavanja.

Tablica 1.

\section{Konfirmativna faktorska analiza (CFA)}

Model mjerenja testiran je upotrebom CFA za sedam latentnih varijabli: vrijednost zadatka, četiri ciljne orijentacije i dvije varijable samoučinkovitosti u kemiji. Svaka promatrana varijabla povezana je sa svakom latentnom varijablom koju je trebala predstavljati. Latentne varijable mogle su korelirati jedna s drugom. Faktorsko težište promatranih varijabli prema zadanim latentnim varijablama za mjerenje sedam faktora prikazano je u tablici 2. Rezultati CFA postigli su sljedeće odgovarajuće vrijednosti: $c^{2}(608)=1574,746, p<0,05 ; \mathrm{NNFI}=0,90 ; C F I=0,91 ; R M S E A=0,053$ $(90 \% \mathrm{CI}=0,050,0,056)$. Te vrijednosti ponudile su dovoljno dokaza za faktorsku valjanost modela mjerenja (Kline, 1998). 
Tablica 2.

\section{Strukturalno modeliranje}

Strukturalno modeliranje (SEM) upotrijebljeno je kako bi se testirale hipoteze u ovome istraživanju. Latentne varijable bile su vrijednost zadatka, četiri vrste ostvarenja cilja (cilj ovladavanja uključivanjem, cilj ovladavanja izbjegavanjem, cilj izvedbe putem uključivanja, cilj izvedbe putem izbjegavanja) i dvije dimenzije samoučinkovitosti u kemiji (CSCS i SCL). Testirali smo dva modela medijacije:

(1) Osnovni model (potpuna medijacija) sastojala se od izravnog puta od vrijednosti zadatka do orijentacija cilja, od orijentacija cilja do samoučinkovitosti u kemiji i od samoučinkovitosti u kemiji do postignuća u kemiji, kao što je i prikazano u slici 1 . Rezultati su ukazali na slabo slaganje s podacima $\left(c^{2}(652)=2008,145, p<, 05\right.$; NNFI $=, 87 ; C F I=, 88 ; R M S E A=, 060 ; 90 \% C I=, 057,, 063)$. U nastojanju da se poboljša slaganje s modelom, ispitali smo indekse modifikacije (MI) (Byrne, 2001). MI predlaže oslobađanje nekoliko kovarijanci pogrešaka, što dovodi do redukcije u vrijednosti $c^{2}$ što za posljedicu ima poboljšanje modela. Zbog teorijske prirode SEM-a trebale bi biti primijenjene samo teorijski značajne modifikacije. Povezali smo pogreške između čestice 6 (Koliko dobro možete opisati strukturu atoma?) i čestice 11 (Koliko dobro možete objasniti prirodu čestice tvari?) $(M I=70,52)$ u CSCS i između čestice 3 (Koliko dobro možete izvesti proceduru eksperimenta u kemijskom laboratoriju?) i čestice 4 (Koliko se dobro možete koristiti opremom u kemijskom laboratoriju?) $(\mathrm{MI}=80,36)$ u SCL-u. Nadalje, strukturalna putanja između čestice 3 (Jako sam zainteresiran za sadržaj predmeta kemija) i čestice 5 (Sviđa mi se sadržaj predmeta kemija) kod vrijednosti zadatka je oslobođena ( $\mathrm{MI}=68,26)$. Takve povezanosti bile su očekivane $s$ obzirom na to da su te čestice $\mathrm{u}$ istoj dimenziji i odražavaju sličan sadržaj.

Drugi CFA imao je bolje indekse slaganja: $c^{2}(649)=1761,646, p<, 05$; NNFI = ,90; $C F I=, 90 ; R M S E A=, 055(90 \% \mathrm{CI}=, 052,0,058)$.

(2) Manje ograničavajući model (parcijalna medijacija) dobiven je dodavanjem izravnih putova od orijentacija cilja do postignuća u kemiji u osnovnom modelu. Nadalje, dodali smo izravan put od vrijednosti zadatka do postignuća u kemiji. Rezultati su pokazali sljedeće indekse slaganja: $c^{2}(644)=1738,109, p<, 05$; NNFI $=, 90 ; C F I=, 90 ; R M S E A=, 055(90 \% \mathrm{CI}=, 051,0,058)$. Kako bismo istražili postoji li potpuna ili parcijalna medijacija, koristili smo se hi-kvadrat testom razlika među osnovnim modelom (potpuna medijacija) i ovim manjeograničavajućim modelom (parcijalna medijacija). Rezultati su pokazali da se manje ograničeni model (parcijalna medijacija) bolje slaže $\left(c^{2}(5, N=572)=23,16 ; p<.05\right)$, što znači da je odnos između orijentacija cilja i postignuća u kemiji parcijalno posredovan samoučinkovitošću u kemiji. Taj je test otkrio da je odnos između vrijednosti zadatka i postignuća u kemiji parcijalno posredovan samoučinkovitošću u kemiji. S obzirom na to da je hi-kvadrat test razlika postigao značajne rezultate i da su rezultati slaganja bili zadovoljavajući, interpretirali smo rezultate manjeograničavajućeg modela (parcijalna medijacija). Slika 
2 pokazuje manjeograničavajući model (parcijalna medijacija) sa standardiziranim koeficijentima smjera.

Slika 2.

Direktni, indirektni i potpuni utjecaji. Tablica 3 ukazuje na standardizirani direktni, indirektni i potpuni utjecaj u manjeograničavajućem modelu (parcijalna medijacija). S obzirom na hipotezu 1 , rezultati upućuju na to da je vrijednost zadatka značajan pozitivan prediktor cilja ovladavanja uključivanjem ( $\mathrm{g}=0,81)$, cilja izvedbe uključivanjem $(g=0,43)$ i cilja ovladavanja izbjegavanjem $(g=0,30)$. Ciljevi ovladavanja uključivanjem $(\mathrm{g}=0,52)$ i ciljevi izvedbe uključivanjem $(\mathrm{g}=0,22)$ uočeni su kao pozitivni prediktori za CSCS, ciljevi ovladavanja izbjegavanjem $(\mathrm{g}=-, 11)$ negativan su prediktor (hipoteza 2). Na kraju, CSCS je značajan prediktor za postignuće u kemiji ( $g=0,15$, hipoteza 3). Cilj ovladavanja izbjegavanjem ima direktan negativan utjecaj na postignuće $\mathrm{u}$ kemiji $(\mathrm{g}=-, 12)$. Direktan utjecaj vrijednosti zadatka na postignuće iz kemije bio je značajan i pozitivan $(\mathrm{g}=, 022)$. Sva ostala terećenja bila su neznačajna.

Tablica 3.

Indirektan utjecaj orijentacija cilja na postignuće iz kemije bio je kroz CSCS i SCL. Ciljevi ovladavanja uključivanjem $(\mathrm{g}=, 08)$ i ciljevi izvedbe uključivanjem $(\mathrm{g}=, 03)$ pozitivno su povezani s uspjehom iz kemije, ciljevi ovladavanja izbjegavanjem ( $\mathrm{g}=$ $-, 03)$ i ciljevi izvedbe izbjegavanjem ( $\mathrm{g}=-, 02)$ negativno su povezani s postignućem iz kemije (Hipoteza 4).Vrijednost zadatka povezana je s postignućem u kemiji $(\mathrm{g}=, 07)$ putem parcijalne medijacije orijentacija cilja i samoučinkovitost u kemiji (Hipoteza 5). Općenito, varijable prediktori objašnjavaju $14 \%$ varijance kod postignuća iz kemije.

\section{Rasprava}

Svrha ovoga istraživanja bila je proučiti odnose između vrijednosti zadatka, organizacija cilja i samoučinkovitosti kod predviđanja postignuća učenika jedanaestog razreda iz kemije. SEM rezultati dali su podršku modelu sa značajnim doprinosom vrijednosti zadatka na cilj izvedbe uključivanjem i cilj ovladavanja izbjegavanjem, na cilj izvedbe uključivanjem i cilj usvajanja izbjegavanjem na CSCS-u i CSCS-a na postignuće u kemiji. Nadalje, ukazano je na pozitivnu, značajnu povezanost između vrijednosti zadatka i postignuća u kemiji i na negativan značajan odnos između cilja ovladavanja izbjegavanjem i postignuća u kemiji.

Vrijednost zadatka pozitivan je prediktor za tri vrste orijentacije cilja, cilj ovladavanja uključivanjem, cilj ovladavanja izbjegavanjem i cilj izvedbe uključivanjem, pri čemu je najveći doprinos uočen za cilj usvajanja uključivanjem, što upućuje na to da učenici koji kemiju doživljavaju kao bitnu i korisnu, imaju tendenciju postaviti ciljeve kako bi razumjeli kemiju za vlastitu kompetentnost, kako bi izbjegli neuspjeh kod kemijskih zadataka i kako bi demonstrirali vlastite sposobnosti u odnosu na druge. U literaturi su ciljevi ovladavanja povezani s visokom vrijednošću zadataka (Greene i Miller, 1996; Greene i sur., 2004; Lau i sur., 2008; Liem i sur., 2008; Rawsthorne i Elliot, 1999). 
Nadalje, vrijednost zadatka pozitivno je predvidjela ciljeve izvedbe putem uključivanja koji se usredotočuju na želju da se bude bolji od ostalih. Prema Greene i sur. (2004) smatraju da se zadatak doživljava kao vrijedan zbog njegove moguće upotrebe u budućnosti ili kako bi pojedinac bio bolji od ostalih. $U$ ovome istraživanju pokazuje se da učenici mogu zadatak smatrati vrijednim zbog oba navedena razloga i tako mogu postaviti ciljeve izvedbe uključivanjem. U Turskoj učenici srednjih škola moraju položiti prijemne ispite kako bi se upisali na fakultete. $U$ ovome ispitu postoje pitanja višestrukog izbora koja provjeravaju znanja i vještine učenika iz nekoliko područja, npr. matematika, kemija, fizika, biologija, povijest i turski jezik i književnost. Rezultati učenika na tim ispitima, uz prosjek ocjena iz srednje škole, uzimaju se kao krajnji rezultat za upis na fakultet (YÖK, 2000). Uzimajući u obzir velik broj kandidata koji svake godine pristupaju tim ispitima, ispit postaje kompetitivan jer visoki rezultati omogućuju nastavak obrazovanja na fakultetima. U ovome istraživanju, uzimajući u obzir ulogu predmeta kemije na učenikov upis na fakultet, učenici bi mogli imati visoku vrijednost zadataka iz kemije te postaviti ciljeve izvedbe uključivanjem kako bi bili bolji od ostalih. Pintrich i Schunk (2007) predložili su da učenici mogu postaviti i ciljeve ovladavanja i ciljeve izvedbe ovisno o karakteristikama sadržaja i njihovim osobnostima. S druge strane, vrijednost zadatka nije uočena kao prediktor za ciljeve izvedbe izbjegavanjem. Štoviše, očekivalo se da će ciljevi izvedbe izbjegavanjem biti negativno korelirani s interesom i vrijednošću zadatka (Pintrich i Schunk, 2007). Usvajanje orijentacija cilja ovisi o osobnim, okolišnim i psihološkim faktorima (Elliot, 1999). Prema tome, u daljnjim će istraživanjima zasigurno biti proučeni razlozi zbog kojih učenici postavljaju ciljeve. Nadalje, vrijednost zadatka parcijalno je posredovana i orijentacijama cilja i samoučinkovitosti u kemiji kako bi se predvidjelo postignuće u kemiji. Taj rezultat podržava prijašnje tvrdnje i ukazuje na značajnu povezanost između vrijednosti zadatka i postignuća (npr., Bong, 2001; Yumusak i sur., 2007).

Sljedeće otkriće iz ovoga istraživanja jest to da ciljevi izvedbe uključivanjem predviđaju samoučinkovitost u kemiji za kognitivne vještine. Drugim riječima, učenici koji se orijentiraju na učenje kemije za vlastitu kompetentnost i da bi bili bolji od ostalih uglavnom imaju veća vjerovanja u samoučinkovitost u kemiji vezana uz kognitivne vještine. To je u skladu s rezultatima drugih istraživanja koja su ukazala na pozitivan odnos između ciljeva ovladavanja uključivanjem i samoučinkovitosti (Dweck i Leggett, 1988; Kaplan i Midgley, 1997; Phan, 2009; Yi i Hwang, 2003). Pintrich i Schunk (2007) smatraju da učenici koji su orijentirani na cilj ovladavanja uglavnom imaju koristi od povratne informacije za vlastiti napredak i tako razvijaju vjerovanje u učinkovitost. Literatura nam ukazuje na nedosljednost u rezultatima o povezanosti samoučinkovitosti i ciljeva izvedbe uključivanjem. Dok istraživači nisu uočili značajan odnos između cilja izvedbe uključivanjem i samoučinkovitosti za učenike osnovnih škola (Anderman i Midgley, 1997), kod učenika je srednjih škola cilj izvedbe uključivanjem povezan sa samoučinkovitošću (Pajares i sur., 2000; Skaalvik, 1997). Midgley (1993) je izjavio da su učenici srednjih škola više orijentirani na 
izvedbu od učenika osnovnih škola. Prema tome, povezanost nije bila iznenađujuća. Kada uzmemo u obzir razrede srednjih škola u Turskoj, a naglašavajući prijemne ispite za fakultete, vjerojatno je da će učenici biti orijentirani prema izvedbi, da će svoja postignuća interpretirati u usporedbi s ostalima i da će razviti vjerovanja o samoučinkovitosti.

Štoviše, ciljevi ovladavanja izbjegavanjem negativno su predvidjeli samoučinkovitost u kemiji za kognitivne vještine. Drugim riječima, učenici koji su ciljeve postavili na način da izbjegnu neuspjeh u zadacima iz kemije, imaju tendenciju niže samoučinkovitosti u kemiji za kognitivne vještine. Taj rezultat u skladu je s Elliotom (1999) koji naglašava negativnu povezanost između ciljeva ovladavanja izbjegavanjem i učeničkih zanimanja o vlastitim sposobnostima za zadatak. Kemija je jedan od onih važnih predmeta kod kojih se može dobiti visok rezultat za prijemne ispite u Turskoj. Nadalje, smatra se teškim predmetom za većinu učenika (Britner i Pajares, 2006; Kennedy, 1996). U ovome istraživanju učenici mogu postaviti ciljeve tako da nema pogrešnog shvaćanja ili neuspjeha u temama iz kemije. Ti učenici uglavnom imaju nisku samoučinkovitost $u$ kemiji za kognitivne vještine i time i niža postignuća.

Samoučinkovitost u laboratoriju za kemiju, s druge strane, nije bila povezana ni $\mathrm{s}$ jednom vrstom orijentacije cilja u ovome istraživanju, što je suprotno hipotezi. Razlog može biti i sama struktura nastave kemije. Uglavnom se nastava kemije u Turskoj temelji na teorijskom poučavanju kemije. Učenici nemaju puno iskustva u provođenju eksperimenata, baratanju kemikalijama, korištenju opremom, u potrebnim kalkulacijama, interpretaciji rezultata eksperimenata u laboratorijima. Takva situacija mogla bi biti razlog za nepronalaženje povezanosti između orijentacija cilja i samoučinkovitosti u laboratoriju za kemiju.

$\mathrm{Na}$ kraju, postignuće iz kemije predviđeno je vjerovanjima o samoučinkovitosti u kemiji za kognitivne vještine. Drugim riječima, što su veća vjerovanja učenika u vlastite sposobnosti za rješavanje zadataka u kemiji, to je veće i njihovo postignuće iz kemije. Rezultati ovog istraživanja upotpunili su dokaze u literaturi o povezanosti samoučinkovitosti i postignuća (npr. Britner i Pajares, 2001; Kupermintz, 2002; Lau i Roeser, 2002; Pintrich i De Groot, 1990). Bandura (1986) je predložio da vjerovanja ljudi o njima samima utječu na njihovo ponašanje, mišljenje i izvedbu. Primjerice, učenici s visokim vjerovanjem u samoučinkovitost u kemiji vrlo vjerojatno će se upustiti u aktivnosti vezane uz kemiju, ustrajat će u suočavanju s poteškoćama, te će na kraju postati uspješni. Bandura smatra da su vjerovanja o samoučinkovitosti bolji prediktori ponašanja od ostalih varijabli, kao što je prijašnje znanje. Prema tome, rezultat ovoga istraživanja, odnosno značajna povezanost između samoučinkovitosti i postignuća, nije iznenađujuć. Međutim, samoučinkovitost u kemijskom laboratoriju nije bila prediktor uspjeha u kemiji. Nedostatno ili nepostojeće iskustvo turskih učenika s laboratorijskim radom može biti razlog takvom rezultatu. Općenito, postignuće u kemiji predviđeno je ciljevima ovladavanja uključivanjem i ciljevima ovladavanja izbjegavanjem putem samoučinkovitosti u kemiji za kognitivne vještine. 
To znači da učenici koji kao cilj postave razvoj vlastitih kompetencije i nadmašivanje ostalih, uglavnom postaju uspješni u kemiji u jedanaestom razredu zahvaljujući visokim vjerovanjima u samoučinkovitost u kemiji za kognitivne vještine. Međutim, učenici koji su kao cilj postavili ovladavanje izbjegavanjem, uglavnom imaju nisko postignuće iz kemije upravo zbog vlastite niske samoučinkovitosti.

Trebalo bi napomenuti da postoji nekoliko ograničenja ovoga istraživanja. Prvo, ovo je istraživanje korelacijsko, stoga ne možemo donositi zaključke o uzročnim vezama. Eksperimentalna istraživanja jamče istraživanja uzročno-posljedičnih veza među varijablama. Drugo, varijable u istraživanju mogle bi biti recipročno povezane jedna $s$ drugom, što bi trebalo istražiti. Treće, $u$ ovome istraživanju kontekst je bio kemija za jedanaesti razred. Daljnja istraživanja potrebna su kako bi se istražila povezanost među varijablama u različitim predmetima i razredima. Četvrto, instrumenti u obliku izvješća korišteni su u ovome istraživanju jer se pretpostavljalo da će učenici dati iskrene odgovore. Daljnje istraživanje uz pomoć različitih izvora za dobivanje podataka (npr., promatranje) moglo bi biti upotrijebljeno kako bi se povećala pouzdanost stvarnih ponašanja i kako bi se smanjila uobičajena metoda odstupanja. Na kraju, pokušali smo predvidjeti postignuće učenika u kemiji preko vrijednosti zadatka, orijentacije ciljeva i samoučinkovitosti. Daljnja istraživanja mogu se osvrnuti na povezanost između postignuća u kemiji i ostalih varijabli poput samoregulacije i strategija učenja.

\section{Praktične implikacije}

Unatoč ograničenjima, rezultati iz ovoga istraživanja dodatak su trenutnom korpusu literature i prakse i upućuju na povezanost između vrijednosti zadatka, orijentacija cilja i samoučinkovitosti u kemiji predviđajući postignuće u kemiji. Posebno zato što je priroda kemije apstraktna i složena pa većina učenika kemiju doživljava kao težak predmet i ima slaba postignuća (Britner i Pajares, 2006; Kennedy, 1996). Rezultati ovoga istraživanja mogli bi biti korisni nastavnicima kako bi poboljšali učenička postignuća. Primjerice, nastavnici bi, u poučavanju, trebali naglasiti važnost kemije u svakodnevnom životu. Trebali bi dati učenicima priliku za upuštanje u više aktivnosti vezane uz kemiju, osvijestiti prijašnje uspjehe iz kemije u zadacima iz kemije i poduprijeti učenike da vjeruju u svoje sposobnosti uspješnog rješavanja zadataka iz kemije. Posjedovanje visoke razine samoučinkovitosti i vrednovanje zadataka u kemiji može doprinijeti visokim postignućem u kemiji. Nadalje, učenici bi trebali biti motivirani za postavljanje ciljeva koji će najbolje pasati u njihov kontekst $\mathrm{i}$ njihove osobne karakteristike i svrhe koje će dovesti do uspjeha. Općenito, nastavnici mogu razviti upute koje će promovirati učeničko razumijevanje kemijskih zadataka, uzimajući u obzir varijable i njihove asocijacije predložene u ovome istraživanju. 